\title{
Primary pulmonary meningioma mimicking pulmonary metastasis: A rare case report
}

\author{
Pulmoner metastazı taklit eden primer pulmoner meningiom: Nadir bir olgu sunumu
}

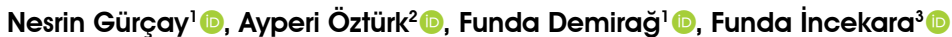

\begin{abstract}
'Department of Pathology, Health Sciences University, Ankara Atatürk Chest Diseases and Thoracic Surgery Training and Research Hospital, Ankara, Turkey 2Department of Interventional Pulmonology, Health Sciences University, Ankara Atatürk Chest Diseases and Thoracic Surgery Training and Research Hospital, Ankara, Turkey ${ }^{3}$ Department of Thoracic Surgery, Health Sciences University, Ankara Atatürk Chest Diseases and Thoracic Surgery Training and Research Hospital, Ankara, Turkey
\end{abstract}

\begin{abstract}
Primary pulmonary meningiomas are rare and mostly benign tumors. They usually appear as a solid peripheral pulmonary nodule on chest radiography and computed tomography and are frequently diagnosed incidentally. Herein, we report a 55-year-old female case of primary pulmonary meningioma mimicking pulmonary metastasis.
\end{abstract}

Keywords: Metastasis, primary pulmonary meningioma, solitary pulmonary nodule.

Meningiomas are the most common intracranial tumors, which occur rarely in the lungs as a primary or metastatic lesion. In the lung, the incidence of metastatic meningiomas is very low and primary pulmonary meningioma (PPM) is even rarer. Since the first case was reported by Kemnitz et al. ${ }^{[1]}$ in 1982, approximately 60 cases of PPM have been reported in the English medical literature. ${ }^{[1]}$ A PPM is usually benign and often appears as a solid pulmonary nodule on chest radiography and computed tomography (CT), which is incidentally detected in the majority of cases. ${ }^{[2]}$

In this report, we present a case of PPM mimicking pulmonary metastasis based on the previous history of a leiomyoma.

\section{$\ddot{O} Z$}

Primer pulmoner meningiomlar nadir görülen ve çoğunlukla benign tümörlerdir. Genellikle göğüs radyografisi ve bilgisayarlı tomografide solid periferik pulmoner nodül şeklinde izlenir ve sıklıkla tesadüfen saptanır. Bu yazıda, pulmoner metastazı taklit eden primer pulmoner meningiomlu 55 yaşında bir kadın olgu sunuldu.

Anahtar sözcükler: Metastaz, primer pulmoner meningiom, soliter pulmoner nodül.

\section{CASE REPORT}

A 55-year-old female patient was admitted with persistent cough for more than two weeks. Her medical history revealed a history of hysterectomy for a uterine leiomyoma 10 years ago and existing asthma for seven years. Physical examination and laboratory test results were normal. A $2 \times 2-\mathrm{cm}$ solitary, peripheral ground-glass nodule was detected in the posterior segment of the right upper lobe of the lung on chest radiography and CT scan (Figure 1). The nodule had a low metabolic activity (maximum standardized uptake value $\left.\left[\mathrm{SUV}_{\max }\right]: 1.89\right)$ on fluorodeoxyglucose positron-emission tomography (FDG-PET). Fiberoptic bronchoscopy revealed no pathological findings. As a result, thoracoscopic wedge resection of the right upper

Received: January 19, 2020 Accepted: April 05, 2020 Published online: October 21, 2020

Correspondence: Nesrin Gürçay, MD. SBÜ, Ankara Atatürk Göğüs Hastalıkları ve Göğüs Cerrahisi Eğitim ve Araştırma Hastanesi, Patoloji Kliniği, 06280 Keçiören, Ankara, Türkiye. Tel: +90 312 - 5677281 e-mail: nesrin_gurcay@hotmail.com 

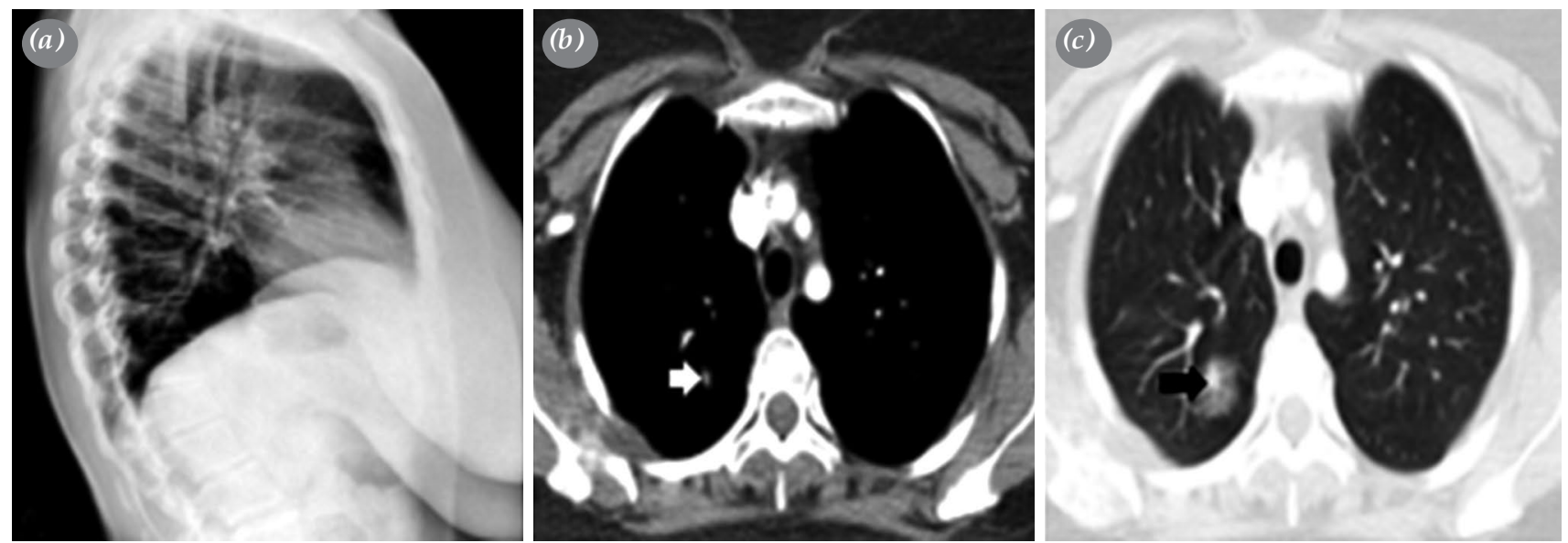

Figure 1. (a) Chest radiography showing nodular opacity in right upper lobe, (b, c) A $2 \times 2-\mathrm{cm}$ solitary ground-glass nodule located in posterior segment of right upper lobe on computed tomography.

lobe was decided. A written informed consent was obtained from the patient.

The patient underwent thoracoscopic wedge resection of the right upper lobe. The wedge resection material was $5 \times 5 \times 3 \mathrm{~cm}$ in size and a $2 \times 2 \times 1.8-\mathrm{cm}$, well-demarcated solitary peripheral nodule was detected. The cut surface of the tumor was yellowishwhite in color. Based on the patient's history and radiological findings, a primary tumor or benign metastatic leiomyoma was initially suspected.

On microscopic examination, however, we observed a large amount of psammoma bodies and a lesion with whorl formation consisting of spindleshaped cells and meningothelial cellular nests without nuclear atypia and mitosis in hematoxylin-eosin (H-E) sections (Figure 2). Immunohistochemical (IHC) analyses demonstrated focal cytoplasmic staining of the epithelial membrane antigen (EMA), strong cytoplasmic staining of S100 protein and Vimentin protein, and nuclear staining of progesterone receptors (PR) on tumor cells. Contrarily, there were no expression for desmin, smooth muscle actin (SMA), and pancytokeratin (panCK) on tumor cells. Based on histomorphological and immunohistochemical features, the patient was diagnosed with a transitional (mixed) type of benign meningioma.

Postoperative intracranial and spinal magnetic resonance imaging revealed no mass at two months after surgery. Therefore, the patient was diagnosed with PPM. The patient is still free from recurrence two years after surgery.

\section{DISCUSSION}

Meningiomas are the most common benign brain tumors originating from meningothelial cells of the arachnoid surface. ${ }^{[3]}$ The incidence of primary extracranial meningioma is very rare $(2 \%)$ and can be
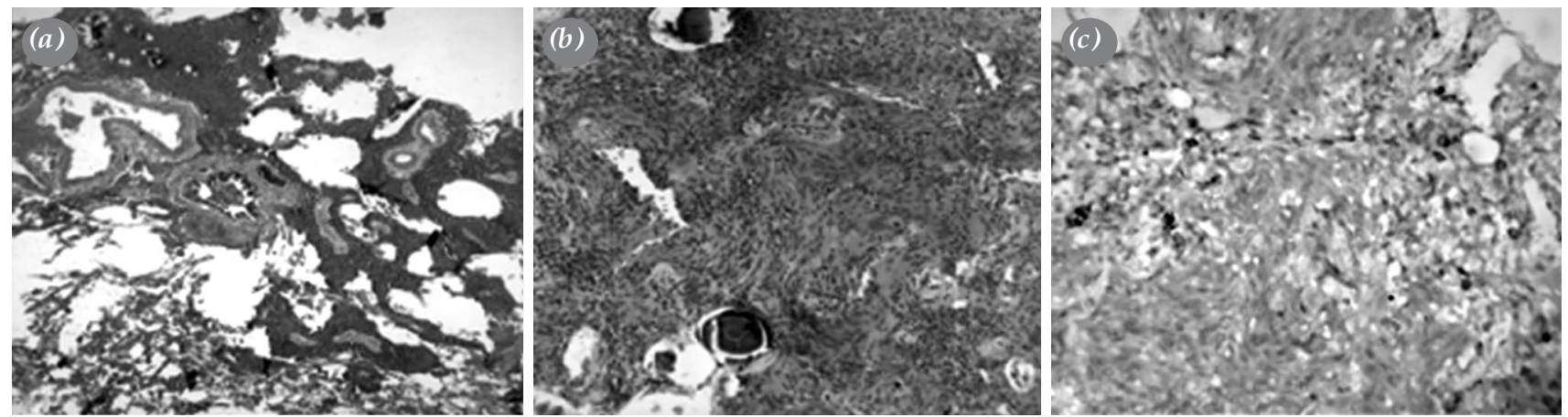

Figure 2. (a) A peripheral pulmonary nodule, $\mathrm{H}-\mathrm{E} \times 40$. (b) Tumor consists of spindle-shaped cells and meningothelial cellular nests with whorl formation and psammoma bodies, H-E $\times 200$. (c) IHC staining of EMA focal positivity, $\times 200$.

H-E: Hematoxylin-eosin; IHC: Immunohistochemical; EMA: Epithelial membrane antigen. 
located in various anatomical sites such as the scalp, nasal sinuses, soft tissue, lungs, parotid gland, adrenal gland, skin, and peripheral nerves. ${ }^{[4]}$

Although its etiology is still unclear, minute pulmonary meningothelial-like nodules, pluripotential cells, heterotrophic embryonic rests, and possible ectopic neuroectodermal tissues in the lung are the most widely adopted theories in the etiology of PPM. ${ }^{[5]}$ In addition, PPM and meningothelial-like nodules show similar histomorphological and immunohistochemical properties; however, genotype characteristics may be different. ${ }^{[2,4]}$ Furthermore, controversial results were reported regarding the incidences of meningioma and meningothelial-like nodules in autopsy series $(0.5 \%$ vs. $0.05 \%$, respectively).

Primary pulmonary meningiomas are more common in adults with a slight female predominance. These tumors may affect all age groups ranging from 18 to 108 years. $^{[6]}$ Although the majority of patients are asymptomatic, some patients may present with chest pain, hemoptysis, cough, or shortness of breath. The tumor size varies from 0.4 to $6 \mathrm{~cm}$ in diameter. Lesions have a high FDG uptake, compatible with malignancy on PET. ${ }^{[5]}$

According to the 2015 World Health Organization classification of the tumors of the lung, PPMs are classified in tumors of ectopic origin..$^{[6]}$ On gross examination, most pulmonary meningiomas have a yellow-tan and homogeneous cut surface. Their cytological and histological findings are also similar to meningiomas of the central nervous system..$^{[6,7]}$ The presence of psammoma bodies, absence of mitotic activity, and focal areas of foamy macrophages are other histological features of PPMs in benign nature. ${ }^{[7]}$ An increased mitotic activity, necrosis, nuclear atypia, and intranuclear inclusions are present in cases of malignant meningiomas. Tumor cells typically express Vimentin and EMA, occasionally and focally express S100 and PR, while cytokeratin, CD34, and neuroendocrine markers are negative. An increased Ki67 proliferation index can be seen in malignant meningiomas. The prognosis of PPM is usually excellent. The surgical approaches are lobectomy or segmentectomy for central lesions and wedge resection for small peripheral nodules. No recurrences or metastasis has been reported in the long-term follow-up of benign cases. However, malignant PPMs may have an aggressive clinical behavior and cause recurrence..$^{[6,7]}$

In the preoperative differential diagnosis of PPMs, sclerosing hemangioma, hyalinizing granuloma, intrapulmonary fibrous tumor, and inflammatory pseudotumor should be considered..$^{[8]}$ According to microscopic examination, spindle cell thymoma, solitary fibrous tumor, well-differentiated neuroendocrine tumor (carcinoid), malignant meningioma, meningothelial-like nodule, meningotheliomatosis, and monophasic synovial sarcoma are the diseases which should be considered in the histopathological differential diagnosis of PPMs. ${ }^{[6]}$

In conclusion, primary pulmonary meningioma is a rare disease and is usually benign in nature. It should be considered in the differential diagnosis of single or multiple pulmonary nodules. A careful pathological, clinical, and radiological examination are required for the definitive diagnosis of primary pulmonary meningioma.

\section{Declaration of conflicting interests}

The authors declared no conflicts of interest with respect to the authorship and/or publication of this article.

\section{Funding}

The authors received no financial support for the research and/or authorship of this article.

\section{REFERENCES}

1. Vaideeswar P, Chaudhari J. Primary pulmonary meningioma. Indian J Pathol Microbiol 2019;62:486-7.

2. Juan CM, Chen ML, Ho SY, Huang YC. Primary Pulmonary Meningioma Simulating a Pulmonary Metastasis. Case Rep Pulmonol 2016;2016:8248749.

3. Murakami K, Takahashi H, Omori T, Uchida O, Hirano H, Kawate N, et al. A case report of resected ectopic malignant meningioma with lung metastasis. Medicine (Baltimore) 2019;98:e15853.

4. Kim YY, Hong YK, Kie JH, Ryu SJ. Primary pulmonary meningioma: an unusual cause of a nodule with strong and homogeneous enhancement. Clin Imaging 2016;40:170-3.

5. Incarbone M, Ceresoli GL, Di Tommaso L, Cappuzzo F, Inzirillo F, Infante M, et al. Primary pulmonary meningioma: report of a case and review of the literature. Lung Cancer 2008;62:401-7.

6. Travis WD, Brambilla E, Burke AP, Marx A, Nicholson AG, editors. WHO Classification of Tumours of the Lung, Pleura, Thymus and Heart. 4th ed. Lyon: World Health Organization; 2015.

7. Gomez-Aracil V, Mayayo E, Alvira R, Arraiza A, Ramón y Cajal S. Fine needle aspiration cytology of primary pulmonary meningioma associated with minute meningotheliallike nodules. Report of a case with histologic, immunohistochemical and ultrastructural studies. Acta Cytol 2002;46:899-903.

8. Luo JZ, Zhan C, Ni X, Shi Y, Wang Q. Primary pulmonary meningioma mimicking lung metastatic tumor: a case report. J Cardiothorac Surg 2018;13:99. 